\title{
Efficient degradation of Malachite Green by Aeromonas sp. strain DH-6
}

\author{
Lin-Na Du ${ }^{1 *}$, Ke-Ke Pan ${ }^{1}$, Gang Li ${ }^{1}$, Yu-Yi Yang ${ }^{2,3}$, Fang-Cheng Xu ${ }^{1}$ \\ ${ }^{1}$ Department of Agriculture and Biotechnology, Wenzhou Vocational College of Science and Technology, Wenzhou 325006, P.R. China \\ ${ }^{2}$ Key Laboratory of Aquatic Botany and Watershed Ecology, Wuhan Botanical Garden, Chinese Academy of Sciences, Wuhan 430074, P.R. \\ China \\ ${ }^{3}$ School of Life Sciences, University of Dundee, Dundee, DD1 5EH, Scotland, United Kingdom
}

\begin{abstract}
Microbial decolorization has been investigated extensively. Various microbes have been studied for their dye removing capability; however, microbial decolorizer with a strong environmental adaptability and wide substrate spectrum is of great potential for its possible practical application. Therefore, in this study, Aeromonas sp. DH-6, a wide dye spectrum decolorizer, was investigated in terms of its use for Malachite Green (MG) remediation. Results indicated that most of carbon sources have no effect on decolorization, while the nitrogen sources of beef extract and yeast extract could enhance MG decolorization significantly. Among the tested metal ions, $\mathrm{Cu}^{2+}, \mathrm{Fe}^{2+}$, and $\mathrm{Zn}^{2+}$ could significantly inhibit decolorization. Moreover, the strain showed a very stable and efficient decolorization performance in the $\mathrm{pH}$ of 5.0-10.0 and at $20-40^{\circ} \mathrm{C}$. Besides, it could almost completely decolorize MG at concentrations $\leqslant 1000 \mathrm{mg} / \mathrm{L}$ within $36 \mathrm{~h}$. Based on UV-visible, GC-MS, and FTIR analysis, biodegradation of MG by the strain DH-6 was confirmed and data showed that MG was decomposed into 4-(Dimethylamino)benzophenone and other metabolites containing $-\mathrm{C}=\mathrm{O},-\mathrm{NH}$, and $-\mathrm{OH}$ groups. Enzyme analysis showed that tyrosinase, laccase, LiP, NADH-DCIP reductase, and MG reductase might be involved in MG degradation by the strain DH-6. Overall, the results demonstrated that the strain DH-6 will have an effective use as an alternative in MG bioremediation.
\end{abstract}

Keywords: Biodegradation; Triphenylmethane dye; Aeromonas sp.; operational parameters; degradation products; enzymes

* Correspondence to:

Lin-Na Du, Department of Agriculture and Biotechnology, Wenzhou Vocational College of Science and Technology, 325006 Wenzhou, Zhejiang, P.R. China; E-mail: dlg1314@126.com

Received: April 28, 2018; Accepted: September 17, 2018; Published Online: November 10, 2018

Citation: Lin-Na Du, Ke-Ke Pan, Gang Li, Yu-Yi Yang, Fang-Cheng Xu, 2018, Efficient degradation of Malachite Green by Aeromonas sp. strain DH-6. http://doi.org/10.26789/AEB.2018.02.005.

Copyright: Efficient degradation of Malachite Green by Aeromonas sp. strain DH-6.@ 2018 Lin-Na Du et al. This is an Open Access article distributed under the terms of the Creative Commons Attribution-Noncommercial 4.0 International License, permitting all non-commercial use, distribution, and reproduction in any medium, provided the original work is properly cited and acknowledged.

\section{Introduction}

Colored wastewater from dye, pigment, textile, and some other industries have become one of the major sources of water pollution. Even less than $1 \mathrm{ppm}$ of dye will make water colored, which will cause light penetration reduction, toxicity to aquatic life, and further inhibit the growth of biota (Sarkar et al., 2014). What's more, with population increase, the requirement of various dyes is also increased. Considering the toxic and non-biodegradable nature of the chemical dyes, it is very essential to treat the effluent containing toxic dyes to make it safety (Sayğılı and Güzel, 2018).

MG is a typical triphenylmethane dye and extensively used in many industries, such as silk, paper, leather, wool, cotton industries, and also as an ectoparasiticide in the aquaculture industry (Yang et al., 2016; Helaili et al., 2017). Every year, thousands of tons of MG were produced and about 10\%-15\% were released to the environment (Yan et al., 2014; Hajnajafi et al., 2018). However, this compound has been proved to have teratogenic, carcinogenic, and mutagenic effects on human bodies, aquatic, and terrestrial animals; thus, MG is banned in many countries including China, US, Canada, and European Union Member Countries (Jasińska et al., 2015; Wu et al., 2018). Nevertheless, it is still illegally used and detected in some countries due to its low cost and high efficiency (Hajnajafi et al., 2018). Therefore, it is crucial to find an effective treatment method of removing MG from water bodies.

Several physicochemical methods have been applied in MG remediation, such as using various adsorbents to remove MG from an aqueous environment (Raval et al., 2017), photocatalytic degradation of MG by various photo-catalysts (Helaili et al., 2017; Meena et al., 2016), oxidation by Fenton reagent (Nidheesh et al., 2013). However, the main concerns of these physicochemical methods are that they are often costly and can produce secondary pollution. Comparatively, biological treatment of $\mathrm{MG}$ is getting more and more attentions since it is an efficient, eco-friendly, and cost 
effective alternative method (Yang et al., 2016). According to the literatures, bacterial strains from Pseudomonas sp. (Du et al., 2011; Tao et al., 2017), Ochrobactrum sp. (Vijayalakshmidevi et al., 2014), Achromobacter xylosoxidans sp. (Wang et al., 2011), Deinococcus radiodurans sp. (Lv et al., 2013), Micrococcus sp. (Du et al., 2012) have been studied to decolorize MG. Although these reported strains have their own advantages for MG decolorization, more effective and adaptable indigenous strains, especially those strains with broad substrate spectrum, should be isolated and studied for MG remediation since most of reported strains still can not be applied in application. Therefore, in this study, a Aeromonas sp. strain DH-6 which is previously studied for degradation of Methyl Orange is investigated due to its excellent MG decolorization capability.

Mechanism of bacterial decolorization has always been attractive. There is a considerable amount of literatures to show the enzymes involved in bacterial decolorization of azo dyes, including azo reductase, tyrosinase, laccase, Mn-peroxidase, lignin peroxidase etc., and also to figure out the degradation products during the process of bacterial decolorization (Khan et al., 2013). However, few is known about the enzymes and degradation products of triphenylmethane dyes. Until now, mechanism of bacterial decolorization of azo dyes is much more clearly than that of triphenylmethane dyes. Thus, more efforts should be made on the enzymes and the degradation products involved in bacterial decolorization of triphenylmethane dyes.

Based on the above background, the strain Aeromonas sp. DH-6 with broad substrate spectrum was investigated to evaluate its MG decolorization ability, and to determine the effect of different operational parameters on the decolorization, as well as to analyze the possible mechanism during the decolorization process.

\section{Materials and methods}

\subsection{Reagents, bacterium, and media}

The typical triphenylmethane dye MG was purchased from Sinopharm Chemical Reagent Company, China. All other chemicals were of reagent/analytical grade. Aeromonas sp. strain DH-6 was isolated from Yanmen tanning mill, Wenzhou, Zhejiang, China, and preserved at China Center for Type Culture Collection (CCTCC NO M2013653). LuriaBertani medium (LB) contained $10.0 \mathrm{~g} / \mathrm{L}$ peptone, $5.0 \mathrm{~g} / \mathrm{L}$ yeast extract, $10.0 \mathrm{~g} / \mathrm{L} \mathrm{NaCl}$, and adjusted $\mathrm{pH}$ to 7.0-7.2. Mineral salt medium (MSM) used in trials of effect of carbon and nitrogen sources on decolorization contained $15.13 \mathrm{~g} / \mathrm{L}$ $\mathrm{Na}_{2} \mathrm{HPO}_{4}, 3.0 \mathrm{~g} / \mathrm{L} \mathrm{KH} \mathrm{KO}_{4}, 0.5 \mathrm{~g} / \mathrm{L} \mathrm{NaCl}, 1.0 \mathrm{~g} / \mathrm{L} \mathrm{NH} 4 \mathrm{Cl}$ (not exist in trials of effect of nitrogen sources), $0.491 \mathrm{~g} / \mathrm{L}$ $\mathrm{MgSO}_{4} \cdot 7 \mathrm{H}_{2} \mathrm{O}, 0.026 \mathrm{~g} / \mathrm{L} \mathrm{CaCl} 2 \cdot 2 \mathrm{H}_{2} \mathrm{O}$, and adjusted $\mathrm{pH}$ to 7.0.

\subsection{Decolorization experiments}

Effect of carbon (2.0 g/L of glucose, lactose, galactose, sucrose, maltose, fructose, xylose, and starch) and nitrogen sources $(2.0 \mathrm{~g} / \mathrm{L}$ of ammonium chloride, sodium nitrate, beef extract, yeast extract, peptone, glutamate, and glycin) on decolorization were conducted in MSM medium at $180 \mathrm{rpm}$, $30^{\circ} \mathrm{C}$. Effect of initial $\mathrm{pH}$ (2.0-10.0), temperature $\left(20-50^{\circ} \mathrm{C}\right)$, metal ions (1.0-3.0 mM of $\mathrm{Cu}^{2+}, \mathrm{Fe}^{2+}, \mathrm{Ca}^{2+}, \mathrm{Zn}^{2+}, \mathrm{Mg}^{2+}$, and $\mathrm{Mn}^{2+}$ ), and dye concentration (100-1000 $\mathrm{mg} / \mathrm{L}$ ) on decolorization were investigated in $2.0 \mathrm{~g} / \mathrm{L}$ of beef extract solution. The strain DH-6 was pre-cultured at $180 \mathrm{rpm}, 30^{\circ} \mathrm{C}$ overnight, and then inoculated to the fresh media at $0.1 \mathrm{~g} / \mathrm{L}$ (dry weight). Each experiment was carried out in triplicate, and decolorization percentage of MG was calculated using the following equation:

$$
D P(\%)=\frac{A_{i}-A_{f}}{A_{i}} \times 100 \%
$$

In which, DP is decolorization percentage of $\mathrm{MG}, \mathrm{A}_{i}$ is the initial absorbance of $\mathrm{MG}$, and $\mathrm{A}_{f}$ is the final absorbance of MG.

\subsection{UV-Visible, GC-MS, and FTIR analysis}

UV-Visible analyses were carried out before and after decolorization at wave length of 200-800 nm using a spectrophotometer (Thermo, Evolution 300 Bio). FTIR analysis was also carried out for determine the products of MG degradation. MG solutions before and after decolorization were centrifuged at 10,000 rpm for $10 \mathrm{~min}$ and the supernatant were analyzed using a Bruker VERTEX 70 infrared spectrometer. The scanned wavelength was from $1000 \mathrm{~cm}^{-1}$ to $3000 \mathrm{~cm}^{-1}$, and the detector system is DigiTect. For gas chromatography-mass spectrometry analysis (GC-MS, Trace GC Ultra and ISQ II MS, Thermo Inc., USA), the cultures containing MG were sampled at set time and extracted using equal volume of trichloromethane. Detailed GC-MS information could be found in our previous studies (Du et al., 2011). Briefly, the column was a TG-1701ms fused silica capillary column ( $30 \mathrm{~m} \times 0.25 \mathrm{~m} \mathrm{id}, 0.25 \mu \mathrm{m})$ with helium as carrier gas at a flow rate of $1 \mathrm{~mL} / \mathrm{min}$. The column temperature was set up programming from $100^{\circ} \mathrm{C}$ to $280^{\circ} \mathrm{C}\left(8^{\circ} \mathrm{C} / \mathrm{min}\right)$, and the injector and detector temperatures were $250^{\circ} \mathrm{C}$. The analysis of the intermediates was carried out in electron ionization (EI) mode at full scan.

\subsection{Enzyme analysis}

Based on published literatures, tyrosinase, laccase, Mnperoxidase $(\mathrm{MnP})$, lignin peroxidase (LiP), NADH-DCIP reductase, and $\mathrm{MG}$ reductase might involve in decolorization (Du et al., 2011; Khan et al., 2013). Therefore, the cells before $(0 \mathrm{~h})$ and after decolorization $(24 \mathrm{~h})$ were collected by centrifugation, and washed 3 times with phosphate buffer (100 mM, pH 7.4). These cells were sonicated at $200 \mathrm{amps}$, giving 99 strokes, at $4^{\circ} \mathrm{C}$, and the mixture was then centrifuged at $12,000 \mathrm{rpm}$ for $15 \mathrm{~min}$ at $4^{\circ} \mathrm{C}$. The supernatant was used for enzyme analysis. The detailed procedures of 
analyzing the enzyme activities are according to our previous researches (Du et al., 2011). One unit of tyrosinase, laccase, MnP, and LiP activities was defined as a change in absorbance unit/mg protein/min. The NADH-DCIP reductase and MG reductase activities were calculated using their extinction coefficients of $90 \mathrm{mM}^{-1} \mathrm{~cm}^{-1}$ and $1.47 \times 10^{5}$ $\mathrm{mM}^{-1} \mathrm{~cm}^{-1}$.

\section{Results and discussion}

\subsection{Decolorization performance of MG by strain DH-6}

\subsubsection{Effect of media components}

Effect of different media components (carbon sources, nitrogen sources, and metal ions) on MG decolorization by strain DH-6 are presented in Figures. 1-3. As shown in Figure 1, after incubation for $6 \mathrm{~h}$, most of tested carbon sources have a slight inhibition on decolorization, while the inhibiting effect would become weaker and weaker with time increase. After incubation for $24 \mathrm{~h}$, most of carbon sources have no effect on decolorization, and with no carbon source addition in MSM, the strain still could decolorize $>94 \%$ of MG $(100 \mathrm{mg} / \mathrm{L})$ after $48 \mathrm{~h}$. Vijayalakshmidevi and Muthukumar (2014) investigated decolorization of MG by Ochrobactrum sp., and it was observed that the strain could decolorize about $80 \%$ of MG (100 mg/L) after incubation for $48 \mathrm{~h}$ in MS media (Vijayalakshmidevi et al., 2014). Chen and Ting (2015) studied biodecolorization potential of MG by Coriolopsis sp., and they reported that MG $(100 \mathrm{mg} / \mathrm{L})$ was the most recalcitrant dye cause the Coriolopsis sp. strain could only decolorize $52 \%$ of MG after 9 days (Chen and Ting, 2015). Comparatively, the strain DH-6 in this study has a great potential in biodecolorization of MG based on its high efficiency.

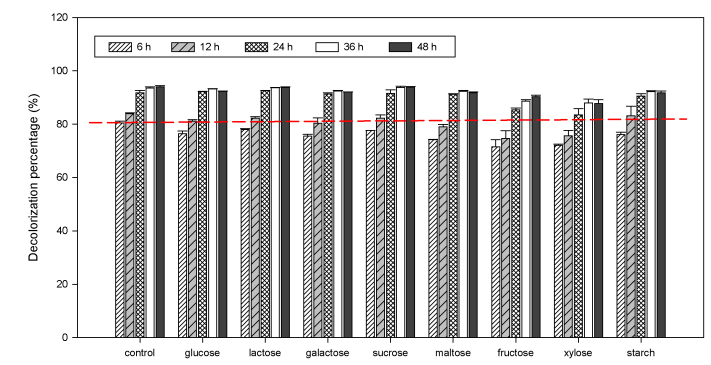

Figure 1. Effect of carbon sources on MG decolorization by strain DH-6.

Data of effect of nitrogen sources on MG decolorization showed that among organic nitrogen sources, beef extract and yeast extract could enhance MG decolorization, while glutamate and glycin have no significant effect on decolorization (Figure 2). The inorganic nitrogen sources ammonium chloride and sodium nitrate would inhibit MG decolorization (Figure 2). However, with time increase, the inhibition caused by ammonium chloride and sodium nitrate would become weaker (Figure 2). Also, it was observed that the strain could remove $>90 \%$ of MG in MSM without additional nitrogen sources after incubation for $6 \mathrm{~h}$, which also indicated its great potential in MG bioremediation (Figure 2).

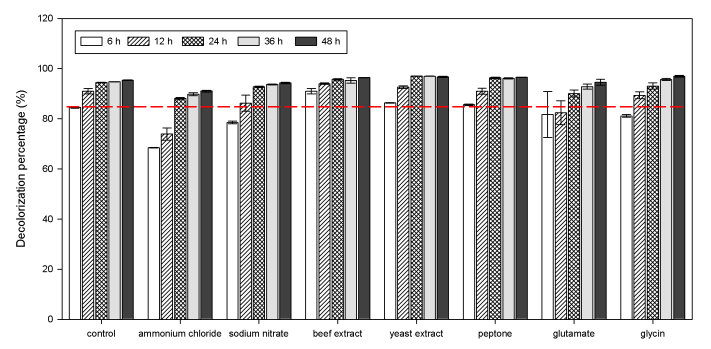

Figure 2. Effect of nitrogen sources on MG decolorization by strain DH-6.

There are various kinds of metal ions in dye-containing wastewaters, and these metal ions might influence dye decolorization. Therefore, it is necessary to test the effect of metal ions on MG decolorization (Yan et al., 2014). Among the tested metal ions, $1.0-3.0 \mathrm{mM}$ of $\mathrm{Ca}^{2+}, \mathrm{Mg}^{2+}$, and $\mathrm{Mn}^{2+}$ have no significant influence on MG decolorization, whereas $\mathrm{Cu}^{2+}, \mathrm{Fe}^{2+}$, and $\mathrm{Zn}^{2+}$ could significantly inhibit decolorization (Figure 3). Besides, with concentration of $\mathrm{Cu}^{2+}, \mathrm{Fe}^{2+}$, and $\mathrm{Zn}^{2+}$ increased, the inhibition would become stronger, and the decolorization was completely blocked when the concentration of $\mathrm{Cu}^{2+}$ and $\mathrm{Fe}^{2+}$ reached to $3.0 \mathrm{mM}$ (Figure 3).

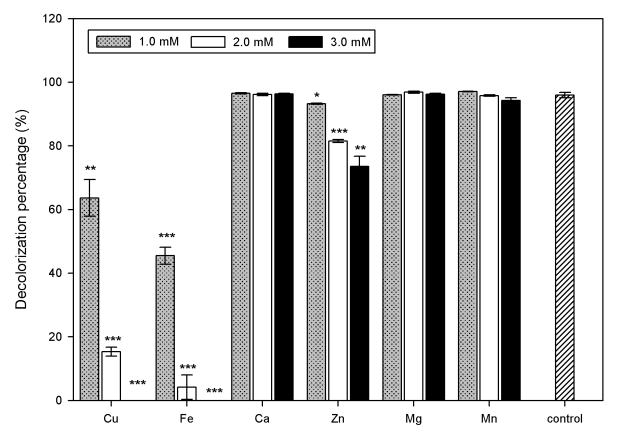

Figure 3. Effect of metal ions on MG decolorization by strain DH-6.

\subsubsection{Effect of $\mathrm{pH}$ and temperature}

To understand the MG decolorization performance of the strain DH-6 at different $\mathrm{pH}$ values ( $\mathrm{pH}$ 2.0-10.0), the decolorization percentages were determined. It was observed that MG decolorization was completely blocked at $\mathrm{pH}<3.0$ even after incubation for $48 \mathrm{~h}$. At $\mathrm{pH} 4.0$, the $\mathrm{MG}$ decolorization percentage by the strain was $20.1 \%$ after $6 \mathrm{~h}$, while it increased significantly with time and MG could be completely decolorized after incubation for $48 \mathrm{~h}$. At $\mathrm{pH}$ 5.0-10.0, the MG decolorization percentages were ranged from $88.6 \%$ to $98.2 \%$ after $6 \mathrm{~h}$, and it was reached to nearly $100 \%$ after incubation for $48 \mathrm{~h}$ at $\mathrm{pH} 4.0-10.0$ (Figure 4). Initial $\mathrm{pH}$ can affect microbial decolorization of MG have been extensively reported previously (Yan et al., 2014; Jasińska et al., 2015; Wang et al., 2011; Jasińska et al., 2012). For different strains, initial $\mathrm{pH}$ values have different effect on their decolorization 
abilities, e.g., in the research of Jasińska et al. 2012, it was observed that the optimal $\mathrm{pH}$ for Penicillium pinophilum was slightly acidic condition of $\mathrm{pH} 4.0$, while it was about 7.0 for Myrothecium roridum (Jasińska et al., 2012); Yan et al. 2014 reported that the optimal $\mathrm{pH}$ for Trametes strains to decolorize MG was pH 6.0 (Yan et al., 2014). According to the literatures, $\mathrm{pH}$ can influence microbial decolorization because it can impact dye molecules transporting through the cellular envelope and also can affect the activity of extracellular redox enzymes involved in decolorization (Jasińska et al., 2015). Besides, in most of literatures, initial pH can influence microbial decolorization in the early incubation stage, while its effect becomes weaker after long time incubation (Jasińska et al., 2015), and our data also support it. Moreover, the strain DH-6 showed a very stable decolorization performance in the $\mathrm{pH}$ range from 5.0 to 10.0 after $6 \mathrm{~h}$ incubation (>88.6\%), indicating its great potential in bioremediation of MG.

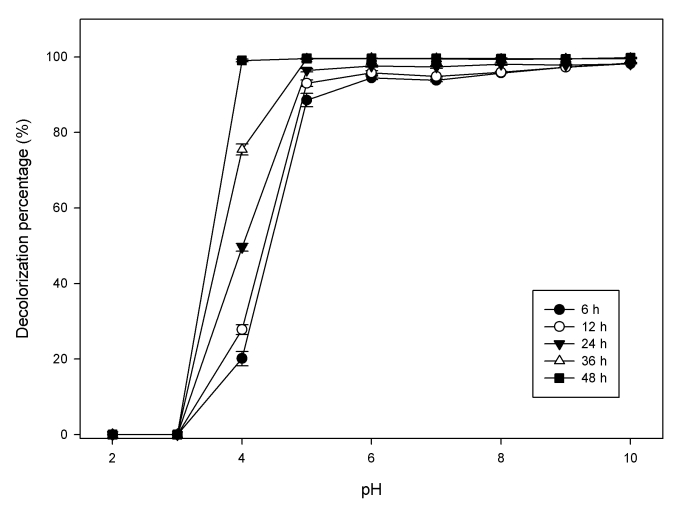

Figure 4. Effect of $\mathrm{pH}$ on MG decolorization by strain DH-6.

Effect of temperature on MG decolorization by the strain DH-6 is showed in Figure 5. At the tested temperatures (20$50^{\circ} \mathrm{C}$ ), the decolorization percentages of MG by the strain after incubation for $6 \mathrm{~h}$ are beyond $89.3 \%$ which indicated that the strain had a good temperature tolerance. Besides, the strain can decolorize $>96 \%$ of $\mathrm{MG}(100 \mathrm{mg} / \mathrm{L})$ after incubation for $6 \mathrm{~h}$, and it can completedly decolorize MG after $48 \mathrm{~h}$ in the temperature range of $20-40^{\circ} \mathrm{C}$; besides, $>90 \%$ of decolorization percentages were still observed after incubation for $48 \mathrm{~h}$ even when the temperature reached to $50^{\circ} \mathrm{C}$. Vijayalakshmidevi and Muthukumar (2014) investigated MG decolorizaiton by Ochrobactrum sp., and they found that incubation temperature could significantly influence MG decolorization, and the decolorization percentage was only about $20 \%$ at $20^{\circ} \mathrm{C}$ (Vijayalakshmidevi et al., 2014). Lv et al. (2013) also observed that temperature could influence MG decolorization by strain Deinococcus radiodurans $\mathrm{R} 1$, and the decolorization efficiency increased from $88.0 \%$ to $97.2 \%$ when temperatures increased from 25 to $45^{\circ} \mathrm{C}$, and then decreased (Lv et al., 2013). Comparatively, strain DH-6 showed an efficient and stable decolorizing ability at $20-50^{\circ} \mathrm{C}$, further suggesting its good potential in MG bioremediation.

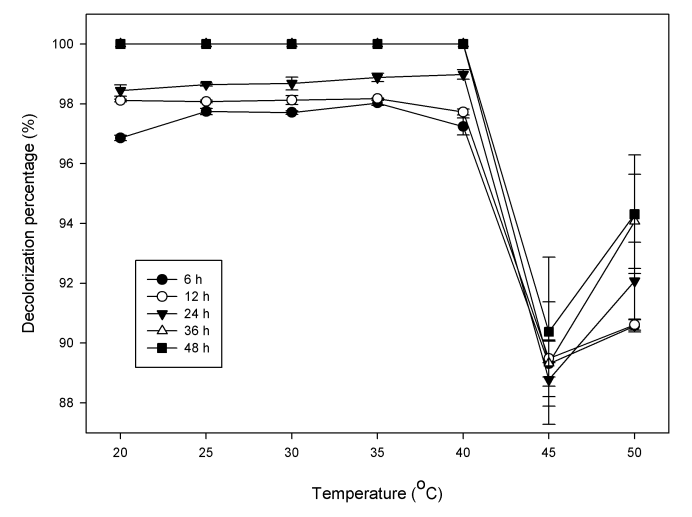

Figure 5. Effect of temperature MG decolorization by strain DH-6.

\subsubsection{Effect of initial dye concentration}

Initial dye concentration is an important factor that can affect dye decolorization. It provides the driving force to overcome mass transfer resistances of the dye molecular between aqueous and solid phases. Thus, MG decolorization by strain DH-6 at different dye concentrations was conducted in this study. As shown in Figure 6, after incubation for 6 h, MG decolorization percentage increased with dye concentrations from $100 \mathrm{mg} / \mathrm{L}$ to $400 \mathrm{mg} / \mathrm{L}$, while it decreased with dye concentrations beyond $400 \mathrm{mg} / \mathrm{L}$. Besides, the strain could decolorize $>92 \%$ of MG at concentrations $\leqslant 1000 \mathrm{mg} / \mathrm{L}$ after incubation for $6 \mathrm{~h}$. Moreover, MG decolorization percentage increased with time, and after $36 \mathrm{~h}$ incubation, the strain could almost completely decolorize MG at concentrations $\leqslant 1000 \mathrm{mg} / \mathrm{L}$. Previous studies indicated that high concentrations of dye could inhibit microbial decolorization even totally block dye decolorization. For example, Jung et al. (2013) studied the effect of MG on the bacterial community in Antarctic soil and the physiology of MG-degrading Pseudomonas sp. MGO (Jung et al., 2013). They observed that MG decolorization percentage decreased from $98.1 \%(50$ $\mathrm{mg} / \mathrm{L}$ ) to $94.9 \%$ (400 mg/L), while it decreased to about $15 \%$ when MG concentration increased to $1000 \mathrm{mg} / \mathrm{L}$. Lv et al. (2013) also observed that MG decolorization percentage decreased from $99.9 \%$ to $64.7 \%$ as dye concentration increase from $50 \mathrm{mg} / \mathrm{L}$ to $500 \mathrm{mg} / \mathrm{L}$. Comparatively, strain DH-6 in this study still showed $>92 \%$ of MG decolorization at dye concentrations $\leqslant 1000 \mathrm{mg} / \mathrm{L}$ after $6 \mathrm{~h}$, suggesting its great potential in MG bioremediation. What's more, previous studies have reported different decolorization trends of $\mathrm{MG}$ with dye concentrations (Lv et al., 2013). Lv et al. (2013) observed a steady decrease of MG decolorization as dye concentration increase from $50 \mathrm{mg} / \mathrm{L}$ to $500 \mathrm{mg} / \mathrm{L}$ (Lv et al., 2013), while Chen et al. (2009) found that MG decolorization efficiency increased as dye concentration increase from $10 \mathrm{mg} / \mathrm{L}$ to 100 mg/L (Chen et al., 2009). In the report of Lv et al. (2013) and Radha et al. (2005), they believe that the relationship between dye concentration and decolorization percentage is not general, whereas the structure of the dye molecular seems to have significant effect on dye decolorization (Lv et al., 2013; Radha et al., 2005). 


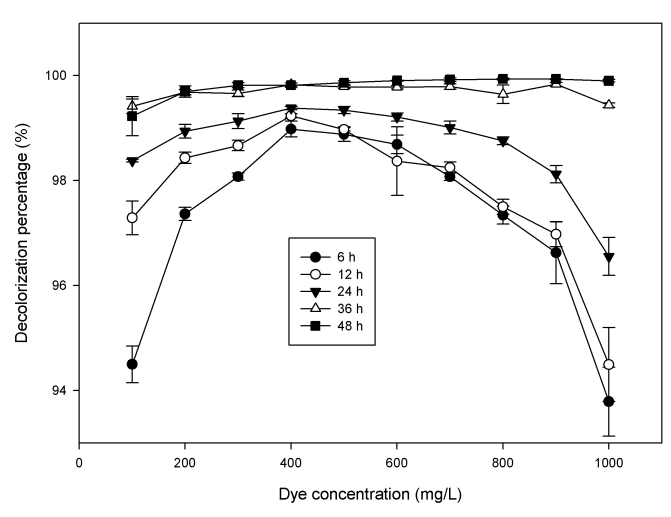

Figure 6. Effect of initial dye concentrations on MG decolorization by strain DH-6.

\subsection{Intermediates analysis of MG degradation}

The MG degradation by strain DH-6 was confirmed by UVVisible, GC-MS, and FTIR analysis (Figures 7-9). We noted that the peak at $620 \mathrm{~nm}$ before decolorization disappear after decolorization, accompanied by formation of new peaks between 300-400 nm. Besides, the peaks at $258 \mathrm{~nm}$ and 205 $\mathrm{nm}$ were increased after decolorization (Figure 7). These observations implied that new compounds were produced after decolorization. MG degradation by strain DH-6 was further confirmed by GC-MS. As shown in Figure 8, MG can not be detected after degradation for $24 \mathrm{~h}$; meanwhile, a new compound was captured with retention time of $14.11 \mathrm{~min}$. After searching for the GC-MS NIST library, the new compound is most likely to be 4-(Dimethylamino)benzophenone (abbreviation: 4-DLBP) since the similarity of the compound to the standards was $79.9 \%$ and the masses of the characteristic fragment ions were $148(\mathrm{M}+, 100), 77$ (62), 225 (35), 105 (25), and 134 (20). The remarkable variations in fingerprint region (3000-1000 cm $\mathrm{cm}^{-1}$ ) of FTIR spectra of MG and its degradation products are shown in Figure 9. It was observed that there are three new peaks at $1648.82 \mathrm{~cm}^{-1}, 1459.86$ $\mathrm{cm}^{-1}$, and $1363.01 \mathrm{~cm}^{-1}$ appeared after degradation, meanwhile the peaks of MG at $1586.8 \mathrm{~cm}^{-1}$ and $1409.73 \mathrm{~cm}^{-1}$ can not be detected after degradation. According to the public reports, the peak at $1648.82 \mathrm{~cm}^{-1}$ corresponding to stretching vibration are caused by the $-\mathrm{C}=\mathrm{O}$ of benzophenone; the peak at $1459.86 \mathrm{~cm}^{-1}$ might be caused by $-\mathrm{NH}$ or $-\mathrm{CN}$ stretching vibrations in amine groups; and the peak at $1363.01 \mathrm{~cm}^{-1}$ might be due to the stretching vibration of the $-\mathrm{OH}$ of phenol (Wu, 1994). Therefore, the degradation products of MG might contain $-\mathrm{C}=\mathrm{O},-\mathrm{NH}$, and $-\mathrm{OH}$ in their molecular. Based on the above analysis, biodegradation of MG by this strain might be firstly hydroxylated to malachite green carbinol or reduced to leucomalachite green, and then further decomposed into 4-DLBP and other metabolites containing $-\mathrm{C}=\mathrm{O},-\mathrm{NH}$, and $-\mathrm{OH}$ groups. These degradation steps were in accordance with biodegradation pathway of MG by Pseudomonas sp. strain DY1 (Du et al., 2011) and Pseudomonas sp. YB2 (Tao et al., 2017). However, due to the deficiency of trace metabolites detection technology, some of degradation products of MG can not be captured directly, which lead to the unclear microbial degradation pathway of MG. Therefore, more efforts will be made on analyzing the trace metabolites in our future researches.

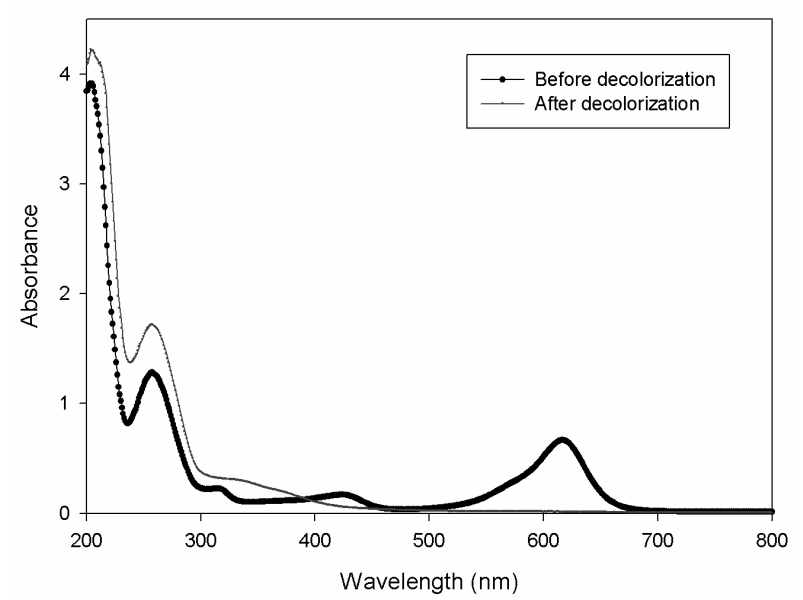

Figure 7. UV-visible spectrum of MG before and after decolorization by strain DH-6.

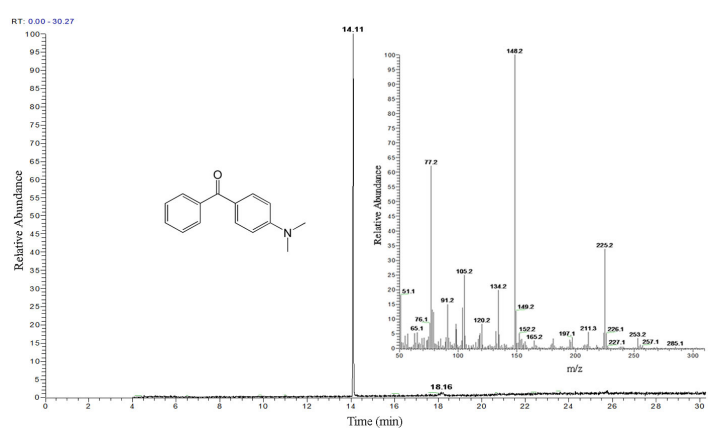

Figure 8. The mass spectras of intermediates of the MG degradation indentified by GC-MS analysis.

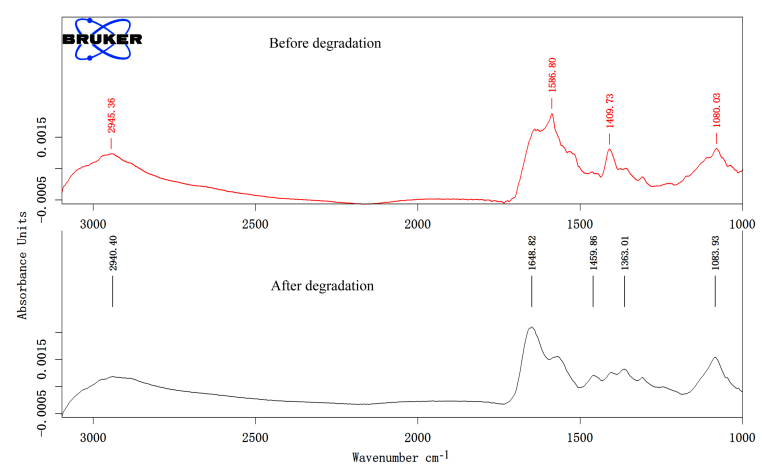

Figure 9. FTIR spectrum of MG before and after decolorization by strain DH-6.

\subsection{Enzyme analysis}

It is commonly accepted that tyrosinase, laccase, MnP, LiP, NADH-DCIP reductase, and MG reductase might be responsible for MG degradation (Yang et al., 2016; Du et al., 2011). Therefore, these enzyme activities were analyzed in this 
study, and the results are shown in Table 1. The activity of tyrosinase after decolorization for $24 \mathrm{~h}$ was significantly higher than that before decolorization (from $0.008 \mathrm{U} \mathrm{mg}$ of protein ${ }^{-1} \mathrm{~min}^{-1}$ to $0.654 \mathrm{U} \mathrm{mg}$ of protein ${ }^{-1} \mathrm{~min}^{-1}$ ), suggesting that tyrosinase could be responsible for MG degradation. Significantly increased enzyme activities after MG decolorization for $24 \mathrm{~h}$ were also observed for laccase, LiP, NADH-DCIP reductase, and MG reductase. As for laccase, the enzyme activity after MG decolorization for $24 \mathrm{~h}$ increased from $0.790 \mathrm{U} \mathrm{mg}$ of protein ${ }^{-1} \mathrm{~min}^{-1}(0 \mathrm{~h})$ to 6.116 $\mathrm{U} \mathrm{mg}$ of protein ${ }^{-1} \mathrm{~min}^{-1}(24 \mathrm{~h})$. The enzyme activity of LiP, NADH-DCIP reductase, and MG reductase after MG decolorization for $24 \mathrm{~h}$ were increased from $3.214 \mathrm{U} \mathrm{mg}$ of protein $^{-1} \mathrm{~min}^{-1}(0 \mathrm{~h})$ to $24.549 \mathrm{U} \mathrm{mg}$ of $\operatorname{protein}^{-1} \mathrm{~min}^{-1}(24$ h), $0.993 \mu \mathrm{g}$ DCIP reduced $\mathrm{mg}$ of $\operatorname{protein}^{-1} \min ^{-1}(0 \mathrm{~h})$ to $2.446 \mu \mathrm{g}$ DCIP reduced $\mathrm{mg}$ of $\operatorname{protein}^{-1} \mathrm{~min}^{-1}(24 \mathrm{~h})$, $19.958 \mu \mathrm{g}$ MG reduced $\mathrm{mg}$ of protein ${ }^{-1} \mathrm{~min}^{-1}(0 \mathrm{~h})$ to 50.855 $\mu \mathrm{g}$ MG reduced $\mathrm{mg}$ of protein ${ }^{-1} \min ^{-1}(24 \mathrm{~h})$, respectively, which indicating that these enzymes also might involve in MG degradation by strain DH-6. Moreover, there is no significant difference of $\mathrm{MnP}$ activity before and after decolorization ( $p$-value $>0.05$ ). Therefore, tyrosinase, laccase, LiP, NADH-DCIP reductase, and MG reductase might be related to MG degradation by strain DH-6. The result is in accordance with previous studies (Yang et al., 2016; Saravanakumar et al., 2014; Chaturvedi and Verma, 2015). Actually, most of researches focused on analyzing several enzymes related to MG degradation, while literature about the clear molecular mechanism of MG degradation is little. Therefore, we will focus on studying molecular mechanism of MG degradation by strain DH-6.

Table 1. The enzyme activities in the cells before $(0 \mathrm{~h})$ and after decolorization $(24 \mathrm{~h})$.

\begin{tabular}{|c|c|c|}
\hline Enzymes & Before & After \\
\hline Tyrosinase $^{\mathrm{a}}$ & $0.008 \pm 0.013$ & $0.654 \pm 0.345^{*}$ \\
\hline Laccase $^{\mathrm{a}}$ & $0.790 \pm 0.148$ & $6.116 \pm 0.261^{* * *}$ \\
\hline Lignin peroxidase $^{a}$ & $3.214 \pm 0.930$ & $24.549 \pm 1.710^{* * *}$ \\
\hline NADH-DCIP reductase ${ }^{b}$ & $0.993 \pm 0.570$ & $2.446 \pm 0.617^{*}$ \\
\hline Mn-peroxidase ${ }^{a}$ & $19.983 \pm 4.521$ & $32.264 \pm 9.610$ \\
\hline MG reductase $\mathrm{c}^{\mathrm{c}}$ & $19.958 \pm 3.179$ & $50.855 \pm 9.775^{* *}$ \\
\hline
\end{tabular}

${ }^{a}$ Enzyme unit/mg of protein/min; ${ }^{b} \mu \mathrm{g}$ DCIP reduced/mg of protein/min; ${ }^{c} \mu \mathrm{g} \mathrm{MG}$ reduced/mg of protein/min; Data are means of triplicate experiments $\pm \mathrm{SD}$. Two-tailed $p$-values comparison was carried out, and

* means $p$-value $\leqslant 0.05$,

** means $p$-value $\leqslant 0.01$,

${ }^{* * *}$ means $p$-value $\leqslant 0.001$.

\section{Conclusions}

Aeromonas sp. DH-6 with high MG degradation ability is studied in this research. The strain still showed high MG decolorization efficiency under a wide $\mathrm{pH}$, temperature, and dye concentration range, suggesting it will have a great ap- plicable potential in MG bioremediation. Effect of different operational parameters on MG degradation by the strain was also studied, and these results will be helpful for practical application of the strain. Moreover, intermediates of MG degradation by strain DH-6 and enzymes related to the decolorization process were also analyzed in this research, and results confirmed microbial MG degradation had a similar degradation pathway and enzyme system. Future studies will focus on analyzing the molecular mechanism of MG degradation by the strain and its practical application.

\section{Acknowledgements}

This study was supported by Wenzhou Science and Technology Major Project (ZS2017001); Basic public welfare research projects in Zhejiang province (LGF18E090007); National Natural Science Foundation of China (31400113).

\section{References}

Chaturvedi, V. and Verma, P., 2015. Biodegradation of malachite green by a novel copper-tolerant Ochrobactrum pseudogrignonense strain GGUPV1 isolated from copper mine waste water. Bioresources and Bioprocessing. 2, 42. https://doi.org/10.1186/s40643-015-0070-8

Chen, C.Y., Kuo, J.T., Cheng, C.Y., Huang, Y.T., Ho, I.H. and Chung, Y.C., 2009. Biological decolorization of dye solution containing malachite green by Pandoraea pulmonicola YC32 using a batch and continuous system. Journal of Hazardous Materials. 172, 1439-1445.

https://doi.org/10.1016/j.jhazmat.2009.08.009

Chen, S.H. and Ting, A.S.Y., 2015. Biodecolorization and biodegradation potential of recalcitrant triphenylmethane dyes by Coriolopsis sp. isolated from compost. Journal of Environmental Management. 150, 274-280. https://doi.org/10.1016/j.jenvman.2014.09.014

Du, L.N., Wang, S., Li, G., Wang, B. and Jia, X.M., 2011. Biodegradation of malachite green by Pseudomonas sp. strain DY1 under aerobic condition: characteristics, degradation products, enzyme analysis and phytotoxicity. Ecotoxicology. 20, 438-446. https://doi.org/10.1007/s10646-011-0595-3

Du, L.N., Zhao, M., Li, G., Zhao, X.P. and Zhao, Y.H., 2012. Highly efficient decolorization of malachite green by a novel Micrococcus sp. strain BD15. Environmental Science and Pollution Research. 19, 2898-2907. https://doi.org/10.1007/s11356-012-0796-1

Hajnajafi, M., Khorshidi, A., Gilani, A.G. and Heidari, B., 2018. Catalytic degradation of malachite green in aqueous solution by porous manganese oxide octahedral molecular sieve (OMS-2) nanorods. Research on Chemical Intermediates. 44 (5), 3313-3323.

Helaïli, N., Boudjamaa, A., Kebir, M. and Bachari, K., 2017. Efficient photo-catalytic degradation of malachite green using nickel tungstate material as photo-catalyst. Environmental Science and Pollution Research. 24, 6481-6491.

Jasińska, A., Paraszkiewicz, K., Sip, A. and Długoński, J., 2015. Malachite green decolorization by the filamentous fungus 
Myrothecium roridum-Mechanistic study and process optimization. Bioresource Technology. 194, 43-48. https://doi.org/10.1016/j.biortech.2015.07.008

Jasińska, A., Różalska, S., Bernat, P., Paraszkiewicz, K. and Długoński, J., 2012. Malachite green decolorization by nonbasidiomycete filamentous fungi of Penicillium pinophilum and Myrothecium roridum. International Biodeterioration \& Biodegradation. 73, 33-40. https://doi.org/10.1016/j.ibiod.2012.06.025

Jung, J., Seo, H., Lee, S.H., Jeon, C.O. and Park, W., 2013. The effect of toxic malachite green on the bacterial community in Antarctic soil and the physiology of malachite greendegrading Pseudomonas sp. MGO. Applied Microbiology and Biotechnology. 97, 4511-4521. https://doi.org/10.1007/s00253-012-4669-9

Khan, R., Bhawana, P. and Fulekar, M.H., 2013. Microbial decolorization and degradation of synthetic dyes: a review. Reviews in Environmental Science and Bio/Technology. 12, 75-97. https://doi.org/10.1007/s11157-012-9287-6

Lv, G.Y., Cheng, J.H., Chen, X.Y., Zhang, Z.F. and Fan, L.F., 2013. Biological decolorization of malachite green by Deinococcus radiodurans $\mathrm{R} 1$. Bioresource Technology. 144, 275-280. https://doi.org/10.1016/j.biortech.2013.07.003

Meena, S., Vaya, D. and Das, B.K., 2016. Photocatalytic degradation of Malachite Green dye by modified $\mathrm{ZnO}$ nanomaterial. Bulletin of Materials Science. 39 (7), 1735-1743. https://doi.org/10.1007/s12034-016-1318-4

Nidheesh, P.V., Gandhimathi, R. and Ramesh, S.T., 2013. Degradation of dyes from aqueous solution by Fenton processes: a review. Environmental Science and Pollution Research. 20, 2099-2132. https://doi.org/10.1007/s11356-012-1385-z

Radha, K.V., Regupathi, I., Arunagiri, A. and Murugesan, T., 2005. Decolorization studies of synthetic dyes using Phanerochaete chrysosporium and their kinetics. Process Biochemistry. 40, 3337-3345. https://doi.org/10.1016/j.procbio.2005.03.033

Raval, N. P., Shah, P.U. and Shah, N.K., 2017. Malachite green "a cationic dye" and its removal from aqueous solution by adsorption. Applied Water Science. 7, 3407-3445.

Saravanakumar, K. and Kathiresan, K., 2014. Bioremoval of the synthetic dye malachite green by marine Trichoderma sp. SpringerPlus. 3, 631. https://doi.org/10.1186/2193-1801-3-631

Sarkar, A.K., Pal, A., Ghorai, S., Mandre, N.R. and Pal, S., 2014, Efficient removal of malachite green dye using biodegradable graft copolymer derived from amylopectin and poly (acrylic acid). Carbohydrate Polymers. 111, 108-115. https://doi.org/10.1016/j.carbpol.2018.02.053

Sayğılı, H. and Güzel, F., 2018. Usability of activated carbon with well-developed mesoporous structure for the decontamination of malachite green from aquatic environments: kinetic, equilibrium and regeneration studies. Journal of Porous Materials. 25, 477-488.

Tao, Y., Wang, F., Meng, L., Guo, Y., Han, M. and Li, J., Cheng, S. and Wang, S., 2017. Biological decolorization and degradation of Malachite Green by Pseudomonas sp. YB2: process optimization and biodegradation pathway. Current Microbiology. 74, 1210-1215. https://doi.org/10.1007/s00284-017-1306-y

Vijayalakshmidevi, S.R. and Muthukumar, K., 2014. Biodegradation of malachite green by Ochrobactrum sp. World Journal of Microbiology and Biotechnology. 30, 429-437. https://doi.org/10.1007/s11274-013-1452-8

Wang, J., Qiao, M., Wei, K., Ding, J., Liu, Z. and Zhang, K.Q. and Huang, X., 2011. Decolorizing activity of Malachite Green and its mechanisms involved in dye biodegradation by Achromobacter xylosoxidans MG1. Journal of Molecular Microbiology and Biotechnology. 20, 220-227. https://doi.org/10.1159/000330669

Wu, J.G., 1994. Modern Fourier Transform Infrared spectroscopy and its application. Scientific and technical documentation press. 573-648.

Wu, J., Feng, Y., Shao, Y., Zhou, J. and Wu, X., 2018. Novel SiQDs-MoS2 heterostructures with increasing solar absorption for the photocatalytic degradation of malachite green. Journal of Materials Science. 53(11), 8120-8131.

Yan, J., Niu, J., Chen, D., Chen, Y. and Irbis, C., 2014. Screening of Trametes strains for efficient decolorization of malachite green at high temperatures and ionic concentrations. International Biodeterioration \& Biodegradation. 87, 109-115. https://doi.org/10.1016/j.ibiod.2013.11.009

Yang, X., Zheng, J., Lu, Y. and Jia, R., 2016. Degradation and detoxification of the triphenylmethane dye malachite green catalyzed by crude manganese peroxidase from Irpex lacteus F17. Environmental Science and Pollution Research. 23, 9585-9597. 